\title{
THE ELEMENTS OF THE MOVIE “KALAM-KALAM LANGIT” AND ITS EFFECT ON VISIT INTENTION OF HALAL TOURISM DESTINATION: THE MEDIATION OF AFFECTIVE IMAGE AND COGNITIVE IMAGE
}

\author{
Wawan Saputra \\ Faculty of Islamic Economics and Business, IAIN Surakarta \\ wawansaputra.se@gmail.com \\ Azis Slamet Wiyono \\ Faculty of Islamic Economics and Business, IAIN Surakarta \\ masazisw@gmail.com
}

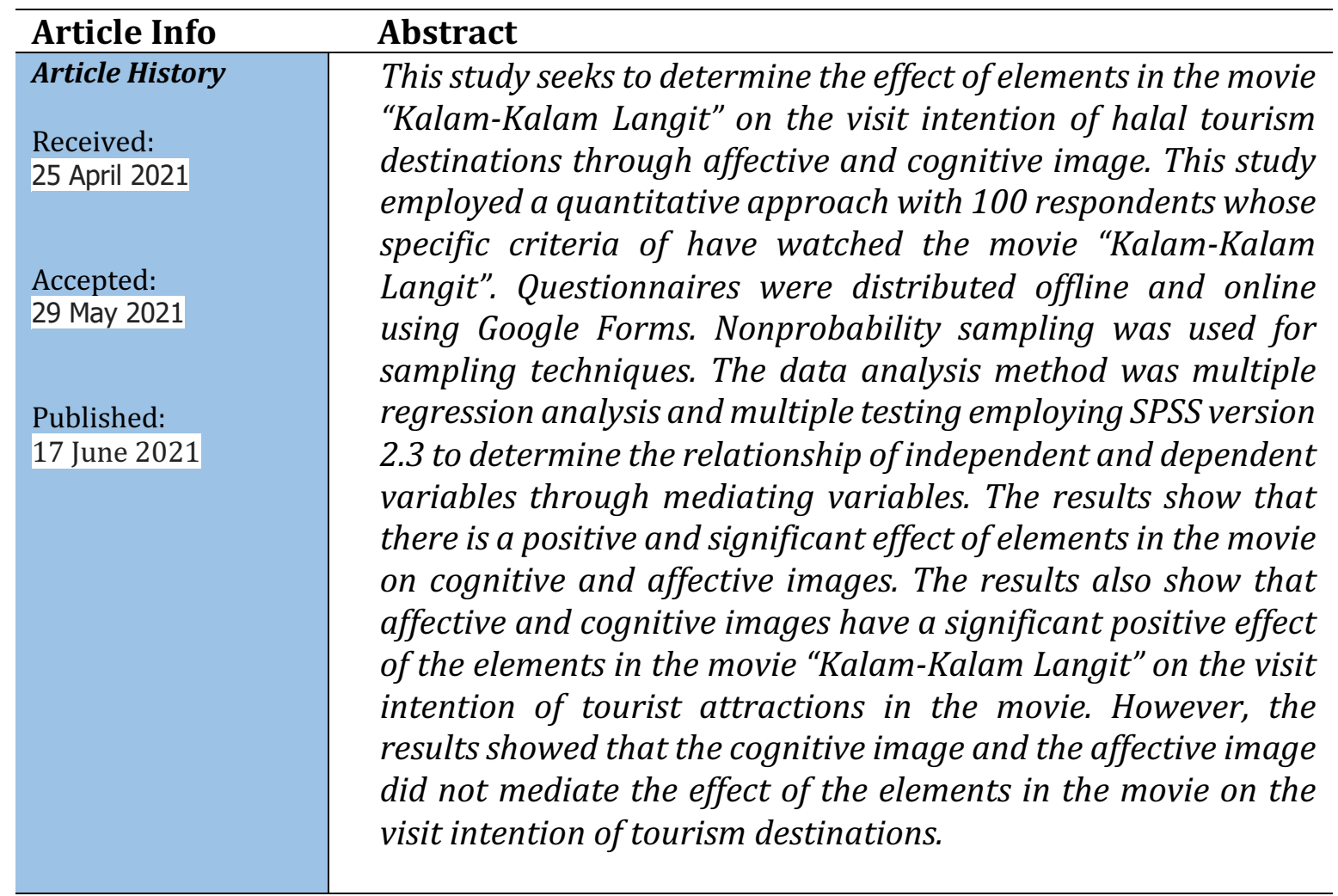

Keywords: Movie Element, Affective Image, Cognitive Image, Visit Intention, Halal Tourism Destination

\section{INTRODUCTION}

Currently, tourism is a promising industrial sector in international trade (Pan, 2011). Tourism is a mainstay sector for driving the economy, especially in countries with limited natural resources. Foreign exchange receipts and employments are the benefits of halal tourism development in a country. Nowadays, in this millennial era tourism has become an absolute necessity for tourists and those living around the tourism destination. 
Indonesian tourism such as culinary, nature, and cultural tourism has been recognized worldwide. Indonesia is one of the ten most popular tourism destinations around the globe (Sari, Safitri, \& Anggraini, 2019). A study conducted in 2016 placed Indonesia in second rank as a popular halal tourism destination in the world. In 2018, the growth of Muslim travelers increased by $6.3 \%$. Indonesia ranks fourth as the country with the largest Muslim travelers with expenditures reaching US\$ 9.7 billion or equivalent to IDR 141 trillion. In addition, Indonesia is currently included in the category of the five best halal tourism destinations in the world (Sari et al., 2019). In total, there are ten halal tourism destinations in Indonesia. They are being developed by the government through the Ministry of Tourism and Creative Economy (Tim Komunikasi Pemerintah Kemenkominfo dan Biro Komunikasi Publik, 2019).

Figure 1. Tourist Visit

Monthly number of international visitors 2019 vs. 2018

*unit: international visit

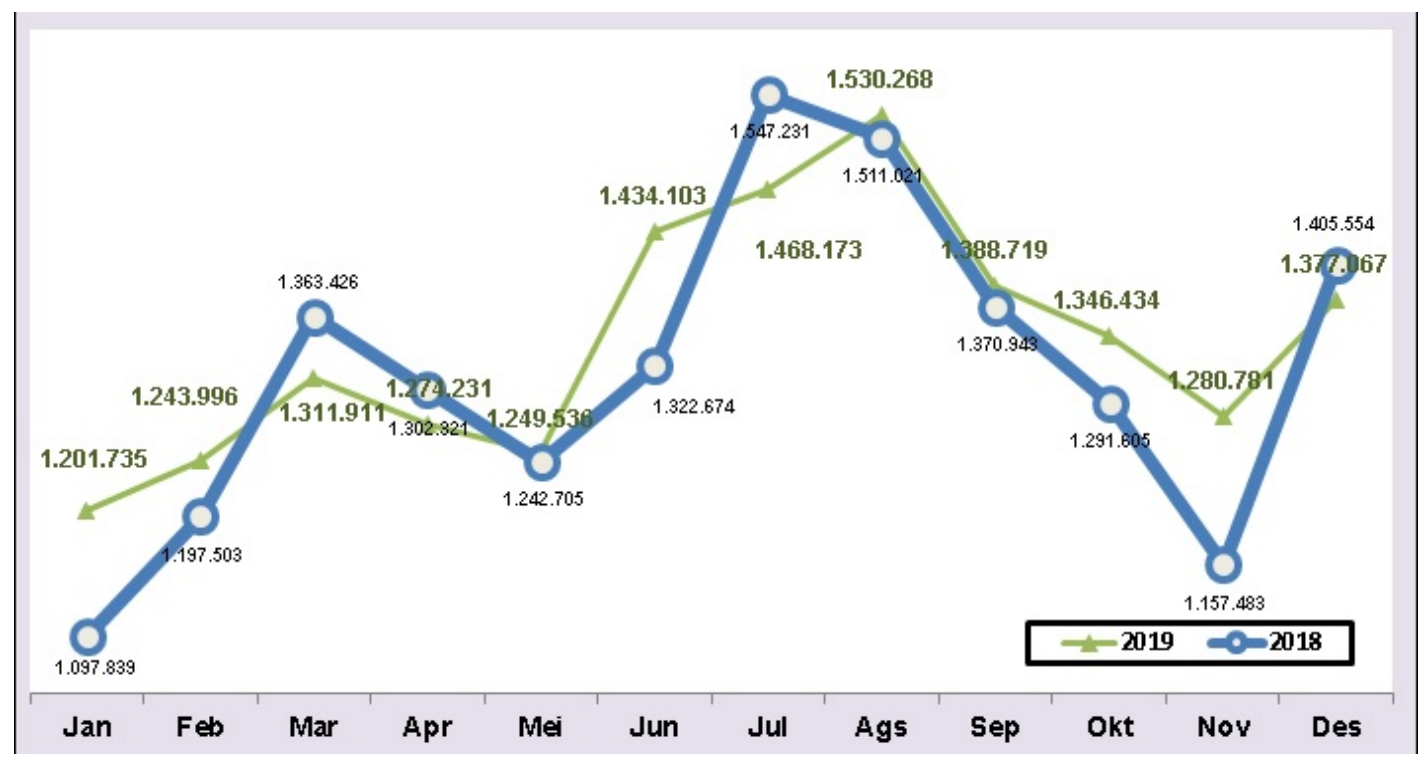

Source: Report from The Ministry of Tourism and Creative Economy (Kemenparekraf), 2020

Data published on the kemenparekraf.go.id site shows the number of foreign tourist arrivals in 2019 reached 16,156,700 tourists from the targeted 20 million tourists. This means that there are issues to be addressed by all related parties since only about $81 \%$ of the target set by the government have been achieved. Meanwhile, in the halal tourism sector, the number of foreign and local tourists visiting West Nusa Tenggara, the island of a thousand mosques, reached 3.7 million tourists. In 2019, the number was considered very small. Indonesia as the largest Muslim country allows regions in Indonesia to build their own strength to meet the needs of Muslim tourists. Halal tourism marks the importance of all aspects such as hotels, transportation, financial systems, and service providers as fundamental things. The selection of halal tourism destinations 
is also a major consideration in applying this concept. Each destination must be following Islamic principles. It starts from having good worship facilities, no nightclubs, and prostitution, and most importantly, the surrounding community supports the concept of halal tourism (Widagdyo, 2015).

Many factors affecting a person in traveling such as needs, external motivation, internal motivation, the environment, and even for millennials, social recognition on social media. Competitiveness among tourism industries triggers a country for tourism marketing. Marketing competition can be won using marketing strategies, such as tourism promotion. Currently, movies and television series can be effective media to market a tourism product. The interest in visiting places in movies is not new among the public. Many people visit a place due to the curiosity of seeing that place in a movie. This phenomenon is commonly called induced tourism, or it can be interpreted as a tourist visit to a place in a movie, series, or video shoot.

One of the many Indonesian movies contributing to tourism is the movie " $5 \mathrm{~cm}$ " taken from a book with the same title written by Donny Dhirgantoro. The book tells about the experiences of five friends who climbed Mount Semeru. However, there are many criticisms against this movie since the audience thinks that there is a lot of heeding of the rules for climbing. One of the problems of tourism in Indonesia is that it is rapidly developing but also fleeting. Another movie that promotes halal tourism destinations in Indonesia is "Kalam-Kalam Langit" which was released in 2016. The movie, starring several famous Indonesian artists and actresses such as Dimas Seto, Meriza Febriani, Elyzia Mulachela, Ibnu Jamil, and several others. The movie itself took a shooting location in Lombok, West Nusa Tenggara, which is actually the rank one halal tourism destination in Indonesia. The shooting location of "Kalam-kalam Langit" in several places in Lombok, one of which is Central Lombok.

There are many studies on the impact of movies on tourist visits since they have an impact on the economy as well as provide benefits in increasing tourist visits (Riley \& Van, 1992). Several recent studies have attempted to empirically study audience involvement whether they choose tourism destinations because they have seen them in movies (S. Kim \& Long, 2012). Another study has also specifically examined whether celebrity involvement affects tourists visits (Samuel Seongseop Kim, Agrusa, Lee, \& Chon, 2007). Theoretically and conceptually, it is suggested that the production elements give the audience the desire to visit a tourism destination (Frost, 2010). In contrast, Loureiro \& Araujo (2015) stated that movies have no effect on someone's visit intention. Thus, the production elements in a movie, as well as audience involvement, have been considered as two main concepts to enrich our understanding of film tourism from an experiential perspective. However, only a few empirical studies of quantitative research methods have 
examined the close relationship between perceived values or perceived elements of visit intention of halal tourism (Seongseop Sam Kim \& Kim, 2017).

Another factor affecting visit intention according to Yang, Yuan, \& Hu (2015), Samuel Seongseop Kim et al. (2007), Frost (2010), dan Whang, Yong, \& Ko, (2015) is the cognitive image whose has a positive and significant effect on visit intention. However, research conducted by Tan \& Wu (2016) describes that cognitive image has a negative effect on visit intention. The research gap from previous studies on the effect of movies on visit attention is important and the increasing development of halal tourism business from year to year. This study was intended to analyze the effect of elements in the movie "Kalam-Kalam Langit" on the visit intention of halal tourism destinations mediated by affective and cognitive images. The findings from this study are expected to be useful for the halal tourism industry in Indonesia to survive. This study can also be used as input for consideration in developing a halal tourism marketing strategy.

\section{LITERATURE REVIEW AND RESEARCH HYPOTHESIS Halal Travel Destinations}

There are numerous definitions of halal tourism. According to the Islamic Tourism CenterMalaysia, halal tourism is every activity, event, and experience carried out in travel following Islamic law. According to Ala-Hamarneh, halal tourism is an economic, cultural, and religious (conservative) concept. According to Duman, halal tourism is all tourist activities carried out by Muslims that come from Islamic motivation and are realized following sharia principles. Henderson describes that halal tourism is all product development and marketing efforts designed for Muslims. Many terminologies are found from the literature that discusses halal tourism such as halal tourism, Islamic tourism, or sharia travel. From these various terminologies, halal tourism and Islamic tourism are most often used (Satriana \& Faridah, 2018).

To support halal tourism in Indonesia, the Indonesian Ulema Council (MUI) through the National Sharia Board (DSN) issued a fatwa regulating the implementation of sharia (halal) tourism that can be used to develop the halal tourism sector in Indonesia. The Fatwa DSN MUI No. 108/DSN-MUI/X/2016 concerning Guidelines for Organizing Tourism based on Sharia Principles regulates all sharia tourism activities, and the terms of a contract (agreement), hotel regulations, tourism destinations, SPA, sauna, massage, travel agency, as well as tour guides.

Halal tourism is a new concept offering tourism but is different from religious tourism such as the pilgrimage or umrah. This halal tourism offers holiday packages that suit the needs of Muslims but still pay attention to Islamic law. Halal tourism is also not an exclusive tour because Muslims and non-Muslims can enjoy services based on halal elements. Halal tourism also covers all aspects such as accommodation, services, lodging, and food (Sari et al., 2019). 


\section{Visit Intention}

Theories regarding visit intention is analogous to buying interest which equates that consumer purchase interest is the same as visit intention. The notion of interest/intention according to Kotler is that interest is a strong internal stimulation that motivates action, in which this impulse is influenced by stimuli and positive feelings for the product (Fitri, Srikandi, \& Andriani, 2015). Interest/intention is also a driving force that causes a person to pay attention to other people or to other objects. Interest/intention itself is a source of motivation for someone to do activities they like (Widagdyo, 2017).

Purchase interest is part of the component of consumer behavior in consuming attitudes, the tendency of respondents to act before the buying decision is taken. Purchase interest in a consumer behavior that shows the extent of commitment to make a purchase. Visit intention is equated with the purchase interest theory and for the indicators, it is measured by the same indicators because before making a visit, consumers/visitors have considerations before deciding to buy a product (Arif, 2017).

\section{"Kalam Langit" Movie}

A movie is an audio-visual communication medium to convey messages. It is a social and cultural document that helps communicate the era when the movie was made even though there was never any intention to do so. In several studies, movies have influenced audiences to visit the movie locations based on the landscape, themes, plots, events, and actors. In addition to the location of filming, the actions performed such as adventures and personalities from movie actors can also affect a visit intention (Ismail, Sumarjan, Khan, \& Hanafiah, 2017).

Some movies tend to appeal to tourists. A movie can be one of the influential media for tourism promotion if the storyline and location are interrelated since the screenings provide a visual depiction of the location of the movie. This can motivate audiences to visit and find information on the location of the movie (Simon Hudson, Wang, \& Gil, 2011). However, the visit intention can be reduced if there are many negative things in the movie that are not countered by the positive things of the tourism destination (Loureiro \& Araujo, 2015).

The movie "Kalam Kalam Langit" was directed by Tarmizi Abka. The script was written by Faozan Rizal. This movie tells the story of the wisdom of the people of West Lombok that is based on the values of the Islamic boarding school (pesantren) and strong Islamic values. This good intention was opposed by his father who always warned him not to sell the divine kalam to gain popularity in the pesantren or expect a gift in return. Ja'far, who was still a kid, got a scholarship from a product offered by the pesantren. 


\section{Destination Image}

Image is a perspective phenomenon that forms a logical-emotional consumer's mind. The image should have both cognitive and emotional components. Meanwhile, the destination image is an individual's perception of destination characteristics that can be influenced by promotional information, mass media, and many other factors (Amalia \& Murwatiningsih, 2016). Image is a real description and does not always have to match the reality (Rakhmat, 2001). Image is also the way society or the public perceives (thinks about) a company or product. An image will give an impression due to an understanding of reality. Thus, this understanding will form perceptions in the audience and form an image (Kotler \& Keller, 2008). Image is formed based on the information we have received. Much of the information conveyed in the mass media is aimed at entertaining or stimulating someone's interest. Information that has been received can have an impact on attitudes and beliefs that are formed from this information in ways that are often not recognized by the recipient and even inadvertently by the communicator (Sharum, 2010).

Tourism destinations include everything in an area including the people, landscapes, industries, and other things that can be part of the destination experience; local specialties that tourists can enjoy even though they are not part of the tourism economy (Hanif, Kusumawati, \& Mawardi, 2016). Thus, the destination image is a picture or individual perception of the place to be visited after obtaining information from various sources. Recent research has seen that the destination image consists of multidimensional constructions consisting of rational interpretations (cognitive images) and emotional (affective images) (Puh, 2014).

\section{Affective Image}

The affective image describes a consumer's emotions or feelings about a particular product or brand. It is an affective component of a certain attitude. This emotion or feeling is often considered by researchers to be highly evaluative in nature, which includes assessment of the object of attitude directly and thoroughly (Yang et al., 2015). The affective image is divided into three dimensions of a vibrant city, exciting city, and fun city (Hanif et al., 2016). Affective image also leads to a response to one's feelings towards the intended object (Mowen \& Minor, 2002). According to Sojung Lee, Busser, \& Yang (2015), affective image refers to a person's feelings about a specific tourism destination. Affective responses vary, for example, positive and negative, pleasure and displeasure, like it or not. Affective image itself is formed by the consumer's emotional assessment of the quality of the destination.

\section{Cognitive Image}

Image is one of the realities that consumers rely on when making choices. Hence, the measurement of the image is an essential tool for consumer analysis. Mowen and Minor (2010) 
state that knowledge is obtained through a cognitive learning process. Cognitive learning is defined as a (active) process where people form associations among concepts, learn sequencing concepts, solve problems, and get input. Cognitive relates to the possibility or tendency that the individual will take special actions or behave in a certain way towards certain attitudes/objects even the conative component may include the actual behavior itself.

Cognitive images are in the form of knowledge, conceptions, and interpretations of a specific place. Cognitive tourism destination image is a person's knowledge and thoughts about an object. With a cognitive approach, the image of a tourism destination is evaluated through the attributes and attractions of the tourism destination that motivate someone to visit (Budi, 2018). Cognitive images show beliefs and attitudes about objects (destination). Individual perceptions are formed from several images that are accepted as internal attributes. Cognitive images are factual information about a destination (Samuel Seongseop Kim et al., 2007).

\section{Research Hypothesis}

\section{The effect of elements in the movie on affective image}

The message conveyed and the shooting background attracts the audience as if audiences feel what is happening in each scene (Loureiro \& Araujo, 2015). Meanwhile, in a study (Yang et al., 2015), the popularity of an actor can affect the feeling of a person watching a movie to follow what he does. Thus, a hypothesis is formulated:

$\mathrm{H}_{1}$ : The elements in the movie affect the affective image

\section{The effect of elements in the movie on cognitive images}

Movies are seen as one of the present culture or popular culture (Sojung Lee et al., 2015). In this study, popular culture, one of which is a movie, affects on a person's cognitive image. A study conducted by Loureiro \& Araujo (2015) analyzed the effect of movies on cognitive images. A hypothesis is formulated as follows:

$\mathrm{H}_{2}$ : The elements in the movie affect the cognitive images

\section{The effect of affective image on visit intention of halal tourism destinations}

A study researching images conducted by Whang et al., (2015). shows consumers' perceptions of quality and influence emotional attractiveness related to the decision-making process (Whang et al., 2015). Another study (Yang et al., 2015) shows that affective image has a positive effect on visit intention. Thus, the following hypothesis is formulated: $\mathrm{H}_{3}$ : Affective image affects the visit intention of halal tourism destinations

\section{The effect of cognitive image on visit intention of halal tourism destinations}

Research on the cognitive image (familiarity and activity) plays an important role in encouraging non-visitors to visit their destination (Tan \& Wu, 2016). In this study, positive 
information displayed in the movie have an impact on consumer behavior to visit a destination. Yang et al., (2015) explained that cognitive images affect the interest in visiting tourism destinations. Thus, the following hypothesis is formulated:

$H_{4}$ : Cognitive image affects the visit intention of halal tourism destinations

\section{The effect of elements in the movie on visit intention of halal tourism destinations}

In a study conducted by Seongseop \& Kim (2017) on the effect of the perceived elements of Korean dramas, it is indicated that the elements in the drama which include characters or celebrities, the message conveyed, and the beauty of the shooting location have an influence on one's interest in decided to travel to places in Korean dramas. Thus, a hypothesis is formulated: $\mathrm{H}_{5}$ : Elements in the movie affect the visit intention of halal tourism destinations

The effect of elements in the movie on visit intention of halal tourist destinations mediated by affective image

Whang et al., (2015) show that affective image affects the Russian to visit South Korea. Affective image provides an overview of a place that creates a stimulus for an audience to feel for themselves the atmosphere at a tourism spot. According to Samuel et al., (2007), affective image has a significant effect on visit intention. In this study, affective image is used as a mediating variable because it has a strong relationship to influence the visit intention. Thus, the following hypothesis is formulated:

$H_{6}$ : Elements in the movie affect the visit intention of halal tourism destination mediated by affective images

The effect of elements in the movie on visit intention of halal tourism destinations mediated by cognitive image

According to S. Hudson \& Ritchie (2006), movies can have a major effect on changes in the number of visits. This is because the audience is motivated by the tourist locations they have seen in the movie. The motivation of tourists to travel is influenced by push and pull motivations. Yang et al. (2010) show that cognitive images have a significant effect on visit intention. This shows that someone is motivated to visit because they get information about a tourist spot (Yang et al., 2015). In this study, cognitive image is used as a mediating variable since it always has a strong relationship to affect the visit intention. Thus, the following hypothesis is formulated:

$H_{7}$ : Elements in the movie affect the visit intention of halal tourism destination mediated by cognitive image 
22 Saputra, W \& Wiyono, A.S., The Elements of the Movie "Kalam-Kalam Langit"...

\section{METHOD}

\section{Population and Sample}

The population in this study are people who have watched the "Kalam-Kalam Langit" movie that was released in 2016. The sample of this study is part of the number and characteristics of the population. In this study, the exact population is not known. Thus, in order to determine the sample size of the study from the existing population, the following formula can be used (Suhartanto, 2014).

$$
\mathrm{E}=\mathrm{Z} \frac{\pi(1-\pi)}{n}
$$

Where:

$$
\begin{array}{ll}
\mathrm{N} & =\text { Number of Samples } \\
\mathrm{Z} & =\text { Normal distribution of } 5 \% \text { (1.96) } \\
\pi & =\text { Proportion of population } \\
\mathrm{E} & =\text { Maximum margin of error }
\end{array}
$$

The maximum margin of error is the maximum tolerable error rate for sampling at $10 \%$. Using this formula, the sample can be formulated:

$$
\begin{aligned}
\mathrm{E} & =(0.5)(1-0.05) \frac{2_{(1.96)}}{0.1} \\
& =96.04
\end{aligned}
$$

\begin{tabular}{|c|c|c|}
\hline Variable & Definition & Indicator \\
\hline \multirow{4}{*}{$\begin{array}{l}\text { Elements in } \\
\text { the Movie } \\
\text { (Seongseop } \\
\text { Sam Kim \& } \\
\text { Kim, 2017) }\end{array}$} & \multirow{4}{*}{$\begin{array}{l}\text { The elements felt by the audience after } \\
\text { seeing or watching a movie consisting } \\
\text { of narrative and cinematographic (Kim } \\
\text { \& Kim, 2017) }\end{array}$} & Actor/actress \\
\hline & & Message conveyed \\
\hline & & $\begin{array}{l}\text { The scenery/ background of } \\
\text { the story }\end{array}$ \\
\hline & & Plot \\
\hline \multirow{4}{*}{$\begin{array}{l}\text { Affective } \\
\text { Image } \\
\text { (Soojin Lee, } \\
\text { Scott, \& } \\
\text { Kim, 2008) }\end{array}$} & \multirow{4}{*}{$\begin{array}{l}\text { Affective image refers to a person's } \\
\text { feelings about a specific tourism } \\
\text { destination (Lee, Scott, \& Kim, 2008). }\end{array}$} & No fun $><$ Fun \\
\hline & & Boring $><$ Rousing \\
\hline & & Gloomy $><$ Interesting \\
\hline & & Sad $><$ Relaxed \\
\hline
\end{tabular}

From the calculation, the sample number was 96.04 and was rounded off to 100 respondents.

\section{Operational Definition of Variables}

Table 1 is the indicators of each variable used in this study:

Table 1. Operational Definition of Variables 


\begin{tabular}{|c|c|c|}
\hline \multirow{4}{*}{$\begin{array}{l}\text { Cognitive } \\
\text { Image } \\
\text { (Artuger, } \\
\text { Cestinoz, \& } \\
\text { Kihc, 2013) }\end{array}$} & \multirow{4}{*}{$\begin{array}{l}\text { Cognitive images show belief or } \\
\text { knowledge about the attributes of a } \\
\text { destination. Individual perceptions are } \\
\text { formed from several images that are } \\
\text { accepted as internal attributes (Artuger } \\
\text { et al., 2013) }\end{array}$} & Nature tourism \\
\hline & & Public infrastructure \\
\hline & & Atmosphere \\
\hline & & Value for money \\
\hline \multirow{3}{*}{$\begin{array}{l}\text { Halal Travel } \\
\text { Intentions } \\
\text { (Seongseop } \\
\text { Sam Kim \& } \\
\text { Kim, 2017) }\end{array}$} & \multirow{3}{*}{$\begin{array}{l}\text { Travel intention is a consumer } \\
\text { behavior that shows the extent of their } \\
\text { commitment to travel (Kim \& Kim, } \\
\text { 2017) }\end{array}$} & Visit interest \\
\hline & & Travel motivation \\
\hline & & Intention for word of mouth \\
\hline
\end{tabular}

\section{RESULTS}

\section{Respondent's Descriptions by Gender}

This study involved 100 male and female respondents. The distribution of respondents based on gender is depicted in Table 2.

Table 2. Respondents based on Gender

\begin{tabular}{|c|c|c|c|}
\hline No. & Gender & Number & Percentage \\
\hline 1 & Female & 78 & $78 \%$ \\
2 & Male & 22 & $22 \%$ \\
\hline \multicolumn{2}{|c|}{ Total } & 100 & $100 \%$ \\
\hline
\end{tabular}

Source: Primary Data Processed (2021)

Table 2 presents that 22 respondents (22\%) were male and 78 respondents $(78 \%)$ were female. It can be concluded that most of those who have watched "Kalam-Kalam Langit" movie are women.

\section{Respondent's Descriptions by Age}

Table 3. Respondents based on Age

\begin{tabular}{|c|c|c|c|}
\hline No. & Gender & Number & Percentage \\
\hline 1 & $17-22$ years old & 87 & $87.9 \%$ \\
2 & $23-28$ years old & 11 & $11.1 \%$ \\
3 & $29-34$ years old & 1 & $1 \%$ \\
\hline
\end{tabular}

Source: Primary Data Processed (2021)

Table 3 shows that most respondents in this study were in the range of 17 to 22 years with 87 respondents $(87.9 \%)$. Respondents in the range of 23 to 28 years were $11(11.1 \%)$. and at the vulnerable age of 29 to 34 years, there is one respondent or $1 \%$ of the total respondents. It can be 
24 Saputra, W \& Wiyono, A.S., The Elements of the Movie "Kalam-Kalam Langit"...

concluded that those who have watched the movie "Kalam-Kalam Langit" are in the age range of 17 to 22 years (millennial).

\section{Respondent's Descriptions by Occupation}

Figure 2. Respondents by Occupation

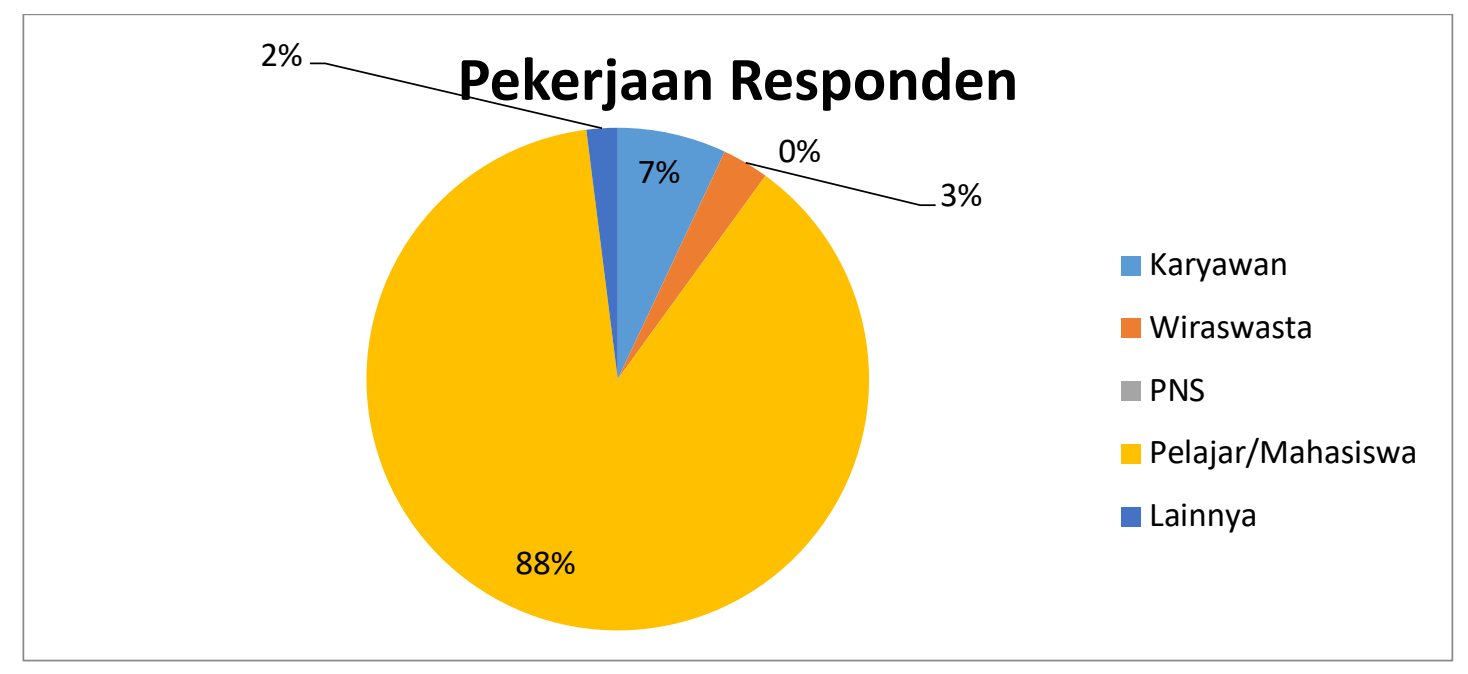

Source: Primary Data Processed (2021)

Figure 2 shows that 88 respondents $(88 \%)$ were students, $7(7 \%)$ respondents were employees, 3 respondents $(3 \%)$ were entrepreneurs, and 2 respondents were from other occupations. It can be concluded that the respondents of this study are students.

\section{Validity and Reliability Test}

Table 4 shows that the value of $r_{\text {coun }}$ on each question item from the variable of elements in the movie: cognitive image, affective image, and visit intention of tourism destinations is greater

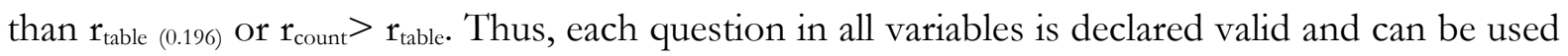
for research. While the reliability test was used to measure a questionnaire which is an indicator of a variable or construct. A construct or variable is said to be reliable if it has a Cronbach's Alpha value of $>0.60$. It can be seen that each instrument in this study is reliable.

Table. 4. Validity and Reliability Tests

\begin{tabular}{|c|c|c|}
\hline Variable & Validity Test & Reliability Test \\
\hline \multicolumn{3}{|c|}{ The Elements of the Movie } \\
\hline UF 1 & 0.754 & \multirow{4}{*}{.834} \\
\hline UF 2 & 0.828 & \\
\hline UF 3 & 0.862 & \\
\hline UF 4 & 0.828 & \\
\hline \multicolumn{3}{|c|}{ Affective Image } \\
\hline CA 1 & 0.689 & \multirow{5}{*}{.762} \\
\hline CA 2 & 0.832 & \\
\hline CA 3 & 0.749 & \\
\hline CA 4 & 0.806 & \\
\hline TW5 & .644 & \\
\hline
\end{tabular}




\section{Cognitive Image}

CK 1

0.778

CK 2

0.795

CK 3

0.769

CK 4

0.802

Visiting Interest

MB 1

0.786

MB 2

0.800

MB 3

0.826

MB 4

0.820

MB 5

0.755

MB 6

0.794

.885

\section{The Classical Assumption Test}

The classical assumption test is used to detect the deviations from the classical assumptions or the multiple regression equation. It consists of the normality test, multicollinearity test, heteroscedasticity test, and autocorrelation test. Based on the results of the normality test using Kolmogorov Smirnov, the significance value of each equation is $0.200>0.05$. Thus, it can be concluded that the residual value is normally distributed. In addition to using a scatter plot, to determine whether heteroscedasticity occurs or not, the Glejser test can be used. The basis for $g$ the Glejser test is, if the significance value (sig.) between the independent variables and the absolute residual is greater than 0.05 , heteroscedasticity does not occur. The tests of each variable showed a value of greater than 0.05 that indicates that heteroscedasticity does not occur. To determine whether there is multicollinearity, it was seen based on the value of tolerance of $>0.10$ and all VIF values are less than 10 . The results show that all variables had a tolerance value of $>0.10$ and a VIF value of $<10$. Thus, it can be concluded that multicollinearity did not occur.

\section{Regression Analysis}

The results of the first stage regression show that there is a positive and significant effect of the elements in the movie on the affective image. The results of the second stage of the regression show a positive and significant effect of the elements in the movie on the cognitive image. The third stage shows that the image in the movie, affective images, and cognitive images have a positive and significant effect on visit intention.

Table 5. Equations of Regression Stage 1, Stage 2, and Stage 3 of Elements in the Movie, Cognitive Image, Affective Image on Visit Intention

\begin{tabular}{|l|l|l|l|l|l|l|}
\hline $\begin{array}{l}\text { Independent } \\
\text { variables }\end{array}$ & $\begin{array}{l}\text { Step 1 (Affective } \\
\text { Image) }\end{array}$ & \multicolumn{2}{c|}{$\begin{array}{c}\text { Step 2 (Cognitive } \\
\text { Image) }\end{array}$} & \multicolumn{2}{l|}{ Step 3 (Visit Intention) } \\
\hline & $\beta$ & $\mathrm{t}$ & $\beta$ & $\mathrm{t}$ & $\beta$ & $\mathrm{t}$ \\
\hline $\begin{array}{l}\text { Elements in the } \\
\begin{array}{l}\text { Movie } \\
\text { Affective Image }\end{array}\end{array}$ & .317 & 4.459 & .231 & 2.810 & .033 & .296 \\
\end{tabular}


26 Saputra, W \& Wiyono, A.S., The Elements of the Movie "Kalam-Kalam Langit"...

\begin{tabular}{|c|crc|c|} 
Cognitive Image & & & .339 & 2.445 \\
\hline & $\mathrm{R} 2=0.169$ & $\mathrm{R} 2=0.075$ & $\mathrm{R} 2=0.418$ \\
& $\Delta \mathrm{R} 2=0.160$ & $\Delta \mathrm{R} 2=0.065$ & $\Delta \mathrm{R} 2=0.400$ \\
& $\mathrm{~F}=19.881^{* *}$ & $\mathrm{~F}=7.899 * *$ & $\mathrm{~F}=23.010^{* *}$ \\
\hline
\end{tabular}

$\mathrm{N}=104 * * \mathrm{p} * *<.01$

\section{Sobel Test}

Table 6. The Mediation of Affective Image and Cognitive Image

\begin{tabular}{|l|l|l|l|l|l|}
\hline No & \multicolumn{1}{|c|}{ Mediating Variable } & $\begin{array}{c}\text { Sobel test } \\
\text { statistic }\end{array}$ & $\begin{array}{c}\text { One-tailed } \\
\text { probability }\end{array}$ & $\begin{array}{c}\text { Two-tailed } \\
\text { probability }\end{array}$ & Result \\
\hline 1 & $\begin{array}{l}\text { Elements of the Movie } \rightarrow \\
\text { Affective Image } \rightarrow \text { Visit } \\
\text { Intention } \\
\text { Elements in the Movie } \rightarrow \\
\text { Cognitive Image } \rightarrow \text { Visit } \\
\text { Intention }\end{array}$ & 0.06500926 & 0.47408331 & 0.94816663 & $\begin{array}{l}\text { No } \\
\text { mediation }\end{array}$ \\
\hline
\end{tabular}

\section{DISCUSSION}

A movie can provide or show what parts and activities are in a tourism destination. There are several elements in the movie that can influence a person's feelings. A movie can also make someone happy or sad and can bring someone to feel like the actor/actress of the movie. A movie can invite visiting a place used as a shooting location. According to Sojung Lee et al., (2015), affective image refers to a person's feelings specifically about a tourism destination used as a filming location, where one can feel every scene in the movie.

The results of this study are supported by research conducted by Loureiro \& Araujo (2015) that the elements in a movie can influence a person's affective feelings or images. This study described the movie "City of God", that in this movie, many negative plots make every viewer feel what is in the film. This movie shows many scenes of crime, cruelty, rape, and robbery. Even so, this film also presents beautiful filming locations in several places in Brazil. Audiences think that one day when they visit Brazil, they will feel the same way as what is in the film.

Currently, mass media is one of the most preferred media to promote various things, including tourism attractions. Movies are one of the promotional media for tourism destinations in Indonesia. According to Loureiro \& Araujo (2015), media such as movies on television or cinemas s well as reviews of tourism destinations on websites play an important role in influencing someone. One of them is influencing the formation of destination images or affective images and cognitive images. The destination image will influence a person's decision later. 
A movie can provide entertainment for the audience. If the filming takes into account what elements can influence a person, a movie can influence someone. Because in a movie there are narrative and cinematic elements, it provides a real visual of the locations used for shooting ( $\mathrm{S}$. Hudson \& Ritchie, 2006). Thus, someone who has watched a movie has information about the destination. travel used for the shooting location. This research is in line with Loureiro \& Araujo (2015) regarding the movie "City of God" with the shooting location in Brazil and gave a negative plot to the city. Hence, get information that Brazil is not a safe city after watching the movie.

Affective image is formed by a person's emotion about the quality of a tourism destination, such as being attractive or unattractive, pleasant or unpleasant, arousing or not after or while watching a movie. This feeling is what will generate the visit intention of a tourism destination. The visit intention can refer to the feelings felt by visitors at a certain time and place (Whang et al., 2015).

This research is supported Whang et al., (2015) who discusses several forms of popular culture such as K-pop, opera, film, and fans club. This research studied Chinese and Russian respondents, in which the higher the involvement in one of these popular cultures, the more the visit intention to Korea and experience the real Korea. Tan \& Wu (2016) research examines a movie featuring filming locations in Hong Kong and the familiarity of Hong Kong with respondents who have visited several places in Hong Kong. In this study, the results show that for those who have visited several places in Hong Kong, their cognitive image is more affected on visit intention than the affective image. Conversely, for those who have never been to places in Hong Kong, their affective image is more affected compared to their cognitive image.

A person's perception is formed from several images that are accepted as internal attributes. The cognitive image itself is factual information about the destination. One's visit intention is influenced by the destination image. Destination image affects consumer behavior and also affects the subjective perception of a tourist. Tourist's perceptions of the destination image consisting of affective images and cognitive images have an important role in visit intention to the decision-making (Sojung Lee et al., 2015). The cognitive image itself shows beliefs and attitudes about the objective of the destination (Yang et al., 2015).

This research is supported by research from Sojung Lee et al., (2015) examining how familiar China's views, events, films, songs, and several other cultures carried out in China obtained from the internet. From this research, it can be seen that the more information respondents received about China, the more they wanted to visit China. A study by Soojin Lee et al., (2008) examining the Korean Wave took both the actor and the singer as the object. The results showed 
that teenagers in Japan who are fans of Ahn Jae-Wook have high visit intention to Korea to meet their favorite actors.

Movies that consist of several narrative elements and cinematic elements provide an overview of tourist destinations. Film can be one of the factors influencing someone's interest in visiting or not. The movies that give a good impression to the audience and are able to influence feelings and also provide information can make someone interested in visiting the location used for filming, but films can also make someone not have the interest to visit the location used for filming because of the scenes in the film it gives a negative image for the audience, therefore the film must present things that are balanced between negative and positive sides.

This study supports research conducted by Warnick et al., (2005) who examined "The Beach" movie starring Leonardo Dicaprio that made students in the United States do not want to visit Thailand because this film shows one of the islands of backpacker's paradise but with very large marijuana plantation.

\section{CONCLUSION AND RECOMMENDATION}

This study shows that there is a significant positive effect on variables studied. However, there is no mediating effect proven in this study. In further research, it is recommended to add other variables to determine the visit intention of tourism destinations, especially halal tourism, since there is still a growing stigma in society that halal tourism is only specifically for the Muslim community. In the future, all parties involved in making movies are expected to continue to innovate creatively as well as participate in supporting tourism in Indonesia, especially halal tourism, which has considerable potential if managed properly. Nowadays, social media can be used to promote tourism to open up more opportunities for the development of tourism in Indonesia. However, the parties involved in making movies are expected to pay attention to many considerations since from the results of this study, some movies do not affect the visit intention. Thus, all parties concerned must be able to make quality movies and support tourism marketing to influence the audience to visit the shooting location. For the government, this can be an alternative to making movies as a medium for promoting tourism in Indonesia, especially halal tourism destinations. The government can cooperate with production houses to jointly make films while promoting tourism in Indonesia.

\section{REFERENCES}

Amalia, I., \& Murwatiningsih. (2016). Pengaruh Citra Destinasi dan Nilai Pelanggan Terhadap Loyalitas Pengunjung Melalui Kepuasan Pengunjung. Management Analysis Journal, 5(3), 257268. 
Arif, wicaksono M. (2017). Pengaruh Media Sosial Instagram @wisatadakwahokura Terhadap Minat Berkunjung Followers. JOM Fisip, 4(2), 1-13.

Artuger, S., Cestinoz, B. C., \& Kihc, I. (2013). The Effect of Destination Image on Destination Loyalty: An Application In The Effect of Destination Image on Destination Loyalty: An Application In Alanya. European Journal of Business and Management, 5(13).

Budi. (2018). Citra Destinasi dan Strategi Pemasaran Destinasi Wisata. Jurnal Business Management, $14,23-36$.

Fitri, A., Srikandi, K., \& Andriani, K. (2015). Pengaruh Word Of Mouth Terhadap Minat Berkunjung Serta Dampaknya Pada Keputusan berkunjung (Survei Pada Pengunjung Tempat Wisata “Jawa Timur Park 2" Kota Batu). Jurnal Administrasi Bisnis, 24(1), 1-6.

Frost, W. (2010). Life Changing Experiences Film and Tourists in The Australian Outback. Annals of Tourism Research, 37(3), 707-726. https://doi.org/10.1016/j.annals.2010.01.001

Hanif, A., Kusumawati, A., \& Mawardi, M. K. (2016). Pengaruh Citra Destinasi Terhadap Kepuasan Wisatawan Serta Dampaknya Terhadap Loyalitas Wisatawan (Studi Pada Wisatawan Nusantara Yang Berkunjung Ke Kota Batu). Jurnal Administrasi Bisnis, 38(1), 44 52.

Hudson, S., \& Ritchie, J. R. (2006). Promoting Destinastions Via Film Tourism: An Empirical Identification Of Supporting Marketing Initiatives. Journal of Travel Research, 44(4), 387-396.

Hudson, Simon, Wang, Y., \& Gil, S. M. (2011). The Influence Of A Film On Destination Image And The Desire To Travel: A Cross-Cultural Comparasion. International Journal Of Tourism Research, 13, 177-190.

Ismail, M. N. I., Sumarjan, N., Khan, N. F. A. H., \& Hanafiah, M. H. (2017). Movie Touring: The In fl uence of Film on Viewers' Travel Intention. Springer Science And Business, 97-108. https://doi.org/10.1007/978-981-10-1718-6

Kim, S., \& Long, P. (2012). Touring TV Soap Operas: Genre in Film Tourism Research. Torist Studies, 12(2), 173-185. https:/ / doi.org/10.1177/1468797612449249

Kim, Samuel Seongseop, Agrusa, J., Lee, H., \& Chon, K. (2007). Effects of Korean Television Dramas on The Flow of Japanese Tourists. Tourism Management, 28, 1340-1353. https://doi.org/10.1016/j.tourman.2007.01.005

Kim, Seongseop Sam, \& Kim, S. (2017). Perceived Values Of Drama, Audince Involvement, And Behavioral Intention In Film Tourism. Journal of Travel \& Tourism Marketing, 00(00), 1-14. https://doi.org/10.1080/10548408.2016.1245172

Kotler, P., \& Keller, K. L. (2008). Manajemen Pemasaran (1st ed.). Jakarta: Erlangga.

Lee, Sojung, Busser, J., \& Yang, J. (2015). Exploring The Dimensional Relationships Among Image Formation Agents, Destinations Image, And Place Attachments From the perspectives Of Pop Star fans. Journal of Travel \& Tourism Marketing, 32(6), 730-746. https://doi.org/10.1080/10548408.2014.934947

Lee, Soojin, Scott, D., \& Kim, H. (2008). Celebrity Fan Involevement And Destination 
Saputra, W \& Wiyono, A.S., The Elements of the Movie "Kalam-Kalam Langit"...

Perceptions. Annals of Tourism Research, 35(3), 809-832. https://doi.org/10.1016/j.annals.2008.06.003

Loureiro, S. M. C., \& Araujo, A. B. de. (2015). Negative Film Plots And Tourists Image And Intentions: The Case Of City Of God. Journal of Travel \& Tourism Marketing, 32, 352-265. https://doi.org/10.1080/10548408.2014.896769

Mowen, J., \& Minor, M. (2002). Perilaku Konsumen (5th ed.; D. K. Yahya, ed.). Jakarta: Erlangga.

Pan, S. (2011). The role of tv commercial visualsin forming memorable and impressive destination images. Journal of Travel Research, 50(2), 171-185.

Puh, B. P. D. (2014). Destination Image and Tourism Satisfaction: The Case of a Mediterranean Destination. Mediterranean Journal of Social Sciences, 5(13), 538-544. https://doi.org/10.5901/mjss.2014.v5n13p0538

Rakhmat, J. (2001). Psikologi Komunikasi. Bandung: P'T. Remaja Rosadakarya.

Riley, R., \& Van, D. (1992). Movies As Tourism Promotion: A Pull Factor In A Push Location. Tourism Management, 13(3), 267-274.

Sari, F. K., Safitri, N., \& Anggraini, W. (2019). Persepsi, Sikap dan Minat Pariwisata Halal di Daerah Istimewa Yogyakarta. Journal of Islamic Economics, Finance, and Bangking, 2(2), 137-155. https://doi.org/https://doi.org/10.12928/ijiefb.v2i2.857

Satriana, E. D., \& Faridah, H. D. (2018). Wisata Halal: Perkembangan, Peluang, dan Tantangan. Journal of Halal Product and Research (JHPR), 01(02), 32-43.

Sharum, L. . (2010). Psikologi Media Entertaiment: Membedah Keampuban Periklanan Subliminal dan Bujukan Yang Tak Disadari Konsumen (1st ed.). Yogyakarta: Jalasutra.

Suhartanto, D. (2014). Metode Riset Pemasaran. Bandung: Alfabeta.

Tan, W.-K., \& Wu, C.-E. (2016). An Investigation Of The relationships Among Destination Familiarity, Destination Image And Future Visit Intention. Journal of Destination Marketing \& Management, 1-13. https://doi.org/10.1016/j.jdmm.2015.12.008

Tim Komunikasi Pemerintah Kemenkominfo dan Biro Komunikasi Publik, K. P. R. (2019). Narasi Tunggal: 5 Tahun Kembangkan Pariwisata Halal, Indonesia Akhirnya Raih Peringkat Pertama Wisata Halal Dunia 2019.

Warnick, R. B., David C, B., \& Siriangkul, A. (2005). Movie Effects on the Image of Thailand Among College Student Travelers. Northeastern Recreation Research Symposium, 355-364.

Whang, H., Yong, S., \& Ko, E. (2015). Pop Culture, Destination Images, And Visit Intentions: Theory And Research On Travel Motivations Of Chinese And Russian Tourists. Journal of Business Research. https://doi.org/10.1016/j.jbusres.2015.06.020

Widagdyo, K. G. (2015). Analisis Pasar Pariwisata Halal Indonesia. The Journal of Taubidinomics, 1(1), $73-80$.

Widagdyo, K. G. (2017). Pemasaran, Daya Tarik Ekowisata dan Minat Berkunjung Wisatawan. 
Esensi: Jurnal Bisnis Dan Manajemen, 7(2), 261-276. https://doi.org/10.15408/ess.v7i2.5411

Yang, J., Yuan, B., \& Hu, P. (2015). Tourism Destination Image and Visit Intention : Examining the Role of Familiarity. Journal of China Tourism Research, 4, 174-187. https://doi.org/10.1080/19388160902910557 